\title{
The contribution of respiration in tree stems to the Dole Effect
}

\author{
A. Angert ${ }^{1}$, J. Muhr ${ }^{2}$, R. Negron Juarez ${ }^{3}$, W. Alegria Muñoz ${ }^{4}$, G. Kraemer ${ }^{4}$, J. Ramirez Santillan ${ }^{4}$, J. Q. Chambers ${ }^{5}$, \\ and S. E. Trumbore ${ }^{2}$ \\ ${ }^{1}$ The Institute of Earth Sciences, The Hebrew University of Jerusalem, Jerusalem, Israel \\ ${ }^{2}$ Department of Biogeochemical Processes, Max-Planck Institute for Biogeochemistry, Jena, Germany \\ ${ }^{3}$ Ecology and Evolutionary Biology, Tulane University, 400 Lindy Boggs, New Orleans, LA, USA \\ ${ }^{4}$ Universidad Nacional de la Amazonía Peruana, Facultad de Ciencias Forestales, Iquitos, Peru \\ ${ }^{5}$ Lawrence Berkeley National Laboratory, Climate Sciences Department, Berkeley, CA, USA
}

Correspondence to: A. Angert (angert@ huji.ac.il)

Received: 16 January 2012 - Published in Biogeosciences Discuss.: 24 January 2012

Revised: 11 September 2012 - Accepted: 27 September 2012 - Published: 22 October 2012

\begin{abstract}
Understanding the variability and the current value of the Dole Effect, which has been used to infer past changes in biospheric productivity, requires accurate information on the isotopic discrimination associated with respiratory oxygen consumption in each of the biosphere components. Respiration in tree stems is an important component of the land carbon cycle. Here we measured, for the first time, the discrimination associated with tree stem oxygen uptake. The measurements included tropical forest trees, which are major contributors to the global fluxes of carbon and oxygen. We found discrimination in the range of 12.6-21.5\% , indicating both diffusion limitation, resulting in $\mathrm{O}_{2}$ discrimination values below $20 \%$, and alternative oxidase respiration, which resulted in discrimination values greater than $20 \%$. Discrimination varied seasonally, between and within tree species. Calculations based on these results show that variability in woody plants discrimination can result in significant variations in the global Dole Effect.
\end{abstract}

\section{Introduction}

The Dole Effect is defined as the difference between the average isotopic composition of oxygen in seawater $\left(\mathrm{H}_{2} \mathrm{O}\right)$, and the oxygen in atmospheric $\mathrm{O}_{2}$. The magnitude of the Dole effect depends mainly on three factors: the isotopic composition of leaf water from which $\mathrm{O}_{2}$ is produced on land (Farquhar et al., 1993; Gillon and Yakir, 2001), the possible isotopic discrimination during release of $\mathrm{O}_{2}$ from $\mathrm{H}_{2} \mathrm{O}$ during photosynthesis (Eisenstadt et al., 2010; Luz and Barkan,
2011); and the discrimination against the heavier isotope in respiratory oxygen consumption (Lane and Dole, 1956; Guy et al., 1989, 1993). The Dole Effect was suggested to be a useful tracer for paleo-changes in the ratio of ocean to land productivity (Bender et al., 1994; Blunier et al., 2002). However, this use is based on the assumption of significantly different isotopic effects of the land and the oceans. New findings, including indications for significant discrimination during marine photosynthesis and the effect of diffusion in soils on the effective respiratory discrimination, have resulted in a decreased estimated difference between the terrestrial and marine Dole Effects, making it easier to explain why there have not been large shifts in the Dole Effect between glacial and interglacial times (Luz and Barkan, 2011).

As shown by previous studies (Angert et al., 2001, 2003; Angert and Luz, 2001), when the diffusion of $\mathrm{O}_{2}$ from the atmosphere to the consumption site inside roots and soil aggregates is restricted, the effective discrimination of the soil system depends not only on the intrinsic discrimination in the respiration processes, but also on the discrimination in diffusion, and on the internal oxygen concentration at the consumption site. This effect of diffusion on the discrimination in $\mathrm{O}_{2}$ uptake is similar to the well known isotopic effect which takes place in $\mathrm{CO}_{2}$ diffusion and uptake in leaves (Farquhar et al., 1982). Overall, the effect of diffusion tends to lower the effective discrimination of $\mathrm{O}_{2}$ uptake in soils (Angert et al., 2003).

However, observations in temperate and boreal forest soils demonstrated that a second process must also act to explain the observed $\delta^{18} \mathrm{O}-\mathrm{O}_{2}$ in soil pore space. This process is 
respiration through the alternative oxidase pathway (AOX). The discrimination of AOX respiration is $\sim 30 \%$ o, which is considerably higher than the $\sim 20 \%$ discrimination in "normal" dark respiration through the cytochrome oxidase pathway (COX) (Ribas-Carbo et al., 1995). High discrimination values $(22.5 \pm 3.6 \%)$ were found in boreal soils (Angert et al., 2003), and can be explained by a large fraction of respiration which goes through the $\mathrm{AOX}$ in plant roots.

The emission of $\mathrm{CO}_{2}$ from aboveground woody tissues amounts to $\sim 16 \%$ of the forest annual gross photosynthesis flux (Litton et al., 2007; Ryan et al., 1997; Waring et al., 1998) while belowground woody tissues contribute a similar amount. As a result, the discrimination in woody tissue $\mathrm{O}_{2}$ uptake may have a significant impact on the global contribution of land to the Dole Effect. To date there have been no measurements of $\mathrm{O}_{2}$ isotope discrimination in tree wood respiration processes. Here we report the first measurements based on stem $\mathrm{O}_{2}$ influx for 6 tree species, representing 4 different plant families, including trees from tropical forests that contribute $\sim 40 \%$ of global land primary production (Beer et al., 2010). Our results suggest that, as with soil respiration, both the effects of diffusion on one hand, and AOX activity on the other, control the isotopic effects in stem $\mathrm{O}_{2}$ uptake.

\section{Methods}

\subsection{Sites and trees}

Trees from two sites were sampled. The first site was the Givat-Ram campus of the Hebrew University of Jerusalem (HUJI, $31^{\circ} 46^{\prime} 15^{\prime \prime} \mathrm{N} 35^{\circ} 11^{\prime} 51^{\prime \prime} \mathrm{E}$ ). At this site we have performed experiments on the following trees: one Apple (Malus domestica), one Stone Pine (Pinus pinea L.), and one Aleppo Pine (Pinus halepensis Mill.). Experiments at this site were conducted from April 2010 to March 2011. The second site was the UNAP site, located at the Center for Research and Forest Learning (CIEFOR) of the National University of the Peruvian Amazon (UNAP) in the community of Puerto Almendras, which is located $16 \mathrm{~km}$ southwest of the city of Iquitos, Peru. CIEFOR is centered over $3^{\circ} 49^{\prime} 53^{\prime \prime} \mathrm{N}, 73^{\circ} 22^{\prime} 28^{\prime \prime} \mathrm{W}$, encompasses a forested area of 1300 ha and belongs to the Faculty of Forest Engineering (FCF)-UNAP. For the base period 1971-2000 the mean annual rainfall is $\sim 3000 \mathrm{~mm}$ (http://www.senamhi.gob.pe/), and the maximum, minimum, and average temperatures are $26.3^{\circ} \mathrm{C}, 25.9^{\circ} \mathrm{C}$, and $25.2^{\circ} \mathrm{C}$, respectively (Brohan et al., 2006). All the experiments in this study were conducted on a total of nine trees from the following species (three each): Tachigali paniculata (Tangarana) and Hymenolobium sp. (Mari-Mari) from the Fabaceae family, and Simaroura amara (Marupa) from the Simaroubaceae family, with a typical wood density value of $0.53,0.65$, and $0.35 \mathrm{~g} \mathrm{ml}^{-1}$, respectively (Chambers et al., 2004). The experiments in the
UNAP site were conducted during the local wet season, from April to May 2011.

\subsection{Stem chambers}

The stem chambers used at the HUJI site are described in Angert and Sherer (2011). Each chamber was constructed from two rectangular clear Perspex parts: (1) a frame base equipped with closed-cell foam on the stem side, and (2) a lid equipped with plastic connectors for sampling and a $60 \mathrm{ml}$ syringe directly connected to it to allow decreasing the system's volume while taking an air sample. The bottom part of the syringe was sawed off to allow good diffusive mixing with the rest of the chamber. The chamber was sealed to the stem by hot glue. For installation on trees where rough bark made it difficult to make an air-tight seal with the chamber base, we first removed some bark, and then smoothed the surface with a file, while being careful not to damage the cambium. In case of smooth-barked trees, we only removed loose bark and lichen before installing the chamber base. After closing the lid, we checked the seal by pulling the piston of the bottomless syringe attached to the lid, and checking for resistance to the pull. This resistance indicates that air could only enter the chamber through small pores in the bark, and hence, in the absence of strong winds (which were avoided during our field campaigns), the mixing between the chambers and the atmosphere was dominated by diffusion. After incubation of 48 to $141 \mathrm{~h}$, the samples of the air in the chamber were collected in pre-evacuated $\sim 3.6 \mathrm{ml}$ glass flasks with a Louwers-Hapert ${ }^{\mathrm{TM}} \mathrm{O}$-ring valve. Before sampling, the dead volume in the tubing and flasks' necks was purged with $30 \mathrm{ml}$ of air from the chamber. In addition to the tree stem experiments, we also set up a blank experiment, to test the possible effect of water vapor diffusion from a stem to the atmosphere. In this experiment we attached a stem chamber to a wood board ( $3.5 \mathrm{~cm}$ thick) that was soaked in water overnight. The board and the chamber were then positioned next to the Apple tree (in August 2012), and the chamber air was sampled after $24 \mathrm{~h}$.

The chambers used in the UNAP site were based on the design reported in Ubierna et al. (2009), and made from polypropylene (PP) tube T-pieces (OD $11 \mathrm{~cm}$, Ostendorf HTRE DN 110) that are equipped with a threaded lid to close one end. The other two ends were welded shut with PP disks. These completely closed T-pieces were then cut longitudinally, thus removing a segment of the tube opposite to the threaded lid, resulting in an opening along the whole length of the tubing $(27.2 \mathrm{~cm})$ and $7.0 \mathrm{~cm}$ wide. The chambers were fit to the shape of the tree stem at the exact spot of installation, and sealed to the stem by hot glue. Leak testing was performed by measuring the chamber $\mathrm{CO}_{2}$ concentration while blowing respiratory air through a piece of tubing on all possibly leaky spots. The $\mathrm{CO}_{2}$ was monitored with an Infra Red Gas Analyzer (IRGA, LI-820 from Li-Cor). Gas from the chamber was pumped through a water 
trap filled with Drierite into the IRGA at a constant flow rate of $\sim 600 \mathrm{ml} \mathrm{min}^{-1}$, and then pumped back into the chamber. The removable chamber lids were equipped with connectors that allowed the $3.6 \mathrm{ml}$ flasks to be directly connected once the lid was sealed. The flask valves were left open to allow $\mathrm{O}_{2}$ to diffuse freely between the sampling flask and the chamber headspace. These flasks were left open and attached for 10 days to ensure that the chamber air reached steady-state between the rate of "leakage" of $\mathrm{O}_{2}$ from the atmosphere, and the rate of consumption of $\mathrm{O}_{2}$ by the stem (see next section). The flasks were then closed and shipped for analysis. The atmospheric pressure monitored in nearby metrological stations was also recorded. Temperature gradients between the stem chamber and the atmosphere can be another source of pressures gradient. In the experiments in Jerusalem this could induce some mass flow, but in the tropical forest experiments the diurnal temperature cycle is small, and this effect was probably negligible. At both sites, the chambers were attached at heights of $\sim 1.6$ to $\sim 2 \mathrm{~m}$ above the ground.

\subsection{Analytical methods}

Sample preparation and mass spectrometry were according to Barkan and Luz (2003). The preparation of the sample included cryogenic removal of water vapor and $\mathrm{CO}_{2}$, and chromatographic separation of $\mathrm{N}_{2}$ by a fully automated system. Elimination of $\mathrm{N}_{2}$ prevented the need for correction for the effect of $\mathrm{N}_{2}$ interference in the ion source of the mass spectrometer. The oxygen concentrations were calculated from the ratio of $\mathrm{O}_{2}$ to $\mathrm{Ar}$ (expressed as $\delta \mathrm{O}_{2} / \mathrm{Ar}$ ), under the assumption of constant Ar concentration. All measurements were performed on a Finnigan-MAT Delta-Plus (Thermo Scientific,Waltham, MA, USA) dual-inlet massspectrometer. The precision in $\delta \mathrm{O}_{2} / \mathrm{Ar}$ was $1 \%$ (which translates to a precision of $0.02 \%$ in $\mathrm{O}_{2}$ concentration), and the precision in $\delta^{18} \mathrm{O}$ determination was $0.03 \%$. All the results are presented with respect to atmospheric air standard (Barkan and Luz, 2003).

\subsection{Models for stem and chamber gases}

Estimating the discrimination associated with stem $\mathrm{O}_{2}$ uptake from the $\delta^{18} \mathrm{O}$ and $\left[\mathrm{O}_{2}\right]$ data requires some simple modeling. Our 1-box analytical model follows a model originally developed for soils (Angert et al., 2001, 2003). In our model, a box represents the chamber and the top layer of the stem, which are assumed to have the same $\mathrm{O}_{2}$ concentration and isotopic composition. The $\mathrm{O}_{2}$ in the box is assumed to be in steady-state. This steady-state results from a balance between $\mathrm{O}_{2}$ diffusion into the box through the bark and outer layer of the stem, and $\mathrm{O}_{2}$ consumption by respiration in the tissues under the chamber.

We assume that advective transport of $\mathrm{O}_{2}$ dissolved in xylem water transiting the area enclosed by the chamber, as well as possible dissolution or exsolution of $\mathrm{O}_{2}$ in this wa- ter, can be neglected compared to respiration consumption of $\mathrm{O}_{2}$. This assumption is reasonable because of the relatively low solubility of $\mathrm{O}_{2}$ in water, which dictates relatively small rates of transport in the xylem water. Even if we assume that the water that arrives at the base of the stem has zero oxygen, this water, at the maximum, could take up dissolved $\mathrm{O}_{2}$ until it is in equilibrium with atmospheric air, or a concentration of roughly $0.25 \mathrm{mmoll}^{-1}$. If we assume, for example, a tree with a stem diameter of $0.5 \mathrm{~m}$, respiration rate of $200 \mathrm{mg} \mathrm{C} \mathrm{m}^{-2} \mathrm{~h}^{-1}$, and xylem water flux of $5001 \mathrm{~d}^{-1}$, the removal of $\mathrm{O}_{2}$ by dissolution will amount to $10 \%$ of the oxygen consumed by respiration up to the height of $1 \mathrm{~m}$. However, above this height the water will be saturated and will not be able to take up more oxygen. We assume that in a more realistic case, the water arrives from the roots close to equilibration with the stem $\mathrm{O}_{2}$ and can take up or lose only small amounts of oxygen compared to respiration fluxes. This will have also only small effect on the $\mathrm{O}_{2}$ isotopes. This also means that $\mathrm{O}_{2}$ produced by corticular photosynthesis outside of the chamber will have negligible effect on the chamber $\delta^{18} \mathrm{O}$. We will also neglect here the possible effect of thermal diffusion, under the assumption that the temperatures at the stem surface and inside it are similar.

Hence, the temporal change in $\mathrm{O}_{2}$ concentrations in the chamber is given by

$\frac{\mathrm{d}\left[\mathrm{O}_{2}\right]_{\mathrm{c}}}{\mathrm{d} t}=I-O-R$,

where the "c" subscript designates the chamber, $I$ is the incoming diffusion flux, $O$ is the outgoing diffusion flux, and $R$ is the consumption flux in the soil. The isotopic composition of the $\mathrm{O}_{2}$ in the chamber will depend on the balance between the entrance of atmospheric $\mathrm{O}_{2}$, which will be affected by discrimination in diffusion, which favors the entrance of light $\left(\right.$ low $\left.{ }^{18} \mathrm{O} /{ }^{16} \mathrm{O}\right)$ oxygen into the chamber headspace, and uptake of $\mathrm{O}_{2}$ by the stem, which removes light oxygen from the chamber headspace. Temporal changes in the $\delta^{18} \mathrm{O}$ value of the chamber $\mathrm{O}_{2}\left(\delta^{18} \mathrm{O}_{\mathrm{c}}\right)$ can be approximated by

$$
\begin{aligned}
\frac{\mathrm{d}\left(\left[\mathrm{O}_{2}\right]_{\mathrm{c}} \cdot \delta^{18} \mathrm{O}_{\mathrm{c}}\right)}{\mathrm{d} t} & =I \cdot\left(\delta^{18} \mathrm{O}_{\mathrm{atm}}-D_{\mathrm{diff}}\right)-O \cdot\left(\delta^{18} \mathrm{O}_{\mathrm{c}}-D_{\mathrm{diff}}\right) \\
& -R \cdot\left(\delta^{18} \mathrm{O}_{\mathrm{c}}-D_{\text {stem }}\right),
\end{aligned}
$$

where $D_{\text {diff }}$ is the ${ }^{18} \mathrm{O}$ discrimination in diffusion in air, and $\delta^{18} \mathrm{O}_{\mathrm{c}}$ and $\delta^{18} \mathrm{O}_{\text {atm }}$ are the $\delta^{18} \mathrm{O}$ values of the chamber and atmospheric $\mathrm{O}_{2}$ respectively. $D_{\text {stem }}$ is the overall ${ }^{18} \mathrm{O}$ discrimination of the $\mathrm{O}_{2}$ uptake by the stem. The $D_{\text {stem }}$ parameter integrates the combined effects of the diffusion in gas phase in the stem, possible diffusion in liquid phase to the consumption site within living cells, and the biochemical uptake by both COX and AOX. Since we are interested in the change in $\delta^{18} \mathrm{O}$ relative to atmospheric oxygen (our primary standard), $\delta^{18} \mathrm{O}_{\text {atm }}$ is zero and can be omitted, and in steady-state we obtain (Angert et al., 2001; Farquhar et al., 1982) :

$D_{\text {stem }}=\frac{\delta^{18} \mathrm{O}_{\mathrm{c}}}{\left(1-\left[\mathrm{O}_{2}\right]_{\mathrm{c}} / 20.95 \%\right)}+14.1 \%$, 
where the values of $20.95 \%$ and $14.1 \%$ are the $\mathrm{O}_{2}$ concentrations in air, and the discrimination associated with $\mathrm{O}_{2}$ diffusion in air, respectively.

Another way to represent the balance between diffusion and uptake is by a numerical model. Our 1-box numerical model is based on the same box and fluxes as the analytical model above. The main difference is that steady-state is not assumed between the box and the atmosphere. Rather, the model is initialized to start with atmospheric air in the box, and the changes in the $\mathrm{O}_{2}$ and $\mathrm{CO}_{2}$ are solved by a finite-difference approach. An example of a model run (with $D=14.1 \%$ o) appears in Fig. 1. As the simpler analytical model predicts, discrimination of $14.1 \%$ is associated with a $\delta^{18} \mathrm{O}$ value of $0 \%$ (i.e. identical to the atmosphere) in steadystate. However, the time-resolving model shows that $\delta^{18} \mathrm{O}$ overshoots to values above $1 \%$ before reaching steady-state. Hence, using the analytical model for a sample taken before the chamber reached steady-state will yield an erroneous estimate of the discrimination value. With the arbitrary conductance used in this example, the steady-state values in isotopic composition are achieved in $\sim 30 \mathrm{~h}$. This isotopic equilibration time is much longer than that required for concentrations to come into equilibration, as has been observed in other systems. Based on previous experiments (Angert and Sherer, 2011) we have estimated that the time needed for the isotopic composition in the stem chamber to reach steadystate is about 24 to $48 \mathrm{~h}$. Consequently, we calculated here the discrimination by Eq. (1), only from chambers' experiments lasting at least $48 \mathrm{~h}$.

The numerical model was also refined to include additional possible effects. One of these effects is the "water vapor flux fractionation effect", which is driven by the diffusion of water vapor (Severinghaus et al., 1996). If a gradient in the concentration of water vapor is present in the outer bark layer, this effect can have some impact on the isotopic composition. A somewhat similar effect can be introduced if the rate of oxygen uptake by the stem exceeds the rate of $\mathrm{CO}_{2}$ emission. This would be accompanied by a reduction in pressure with a consequent mass flow of atmospheric air into the box. This will not only bring in $\mathrm{O}_{2}$, but also $\mathrm{N}_{2}$ and Ar. As a result, $\mathrm{N}_{2}$ and Ar concentrations in the stem will increase, and the $\mathrm{O}_{2} /$ Ar ratio will not simply indicate $\mathrm{O}_{2}$ concentrations. We thus included all the relevant gases in our model, and assumed that any pressure gradient will be compensated by mass flow. Using this version of the model we found that these effects are small and tend to cancel out, so that even if we assume that the outer bark has a relative humidity as low as $60 \%$, or the $\mathrm{CO}_{2} / \mathrm{O}_{2}$ fluxes have a ratio of 0.5 , the error in the estimation of $D$ by Eq. (3) will be $<0.3 \%$, and thus can be neglected. To further confirm the conclusion that the water vapor effect is negligible, we have performed the blank experiment described above.

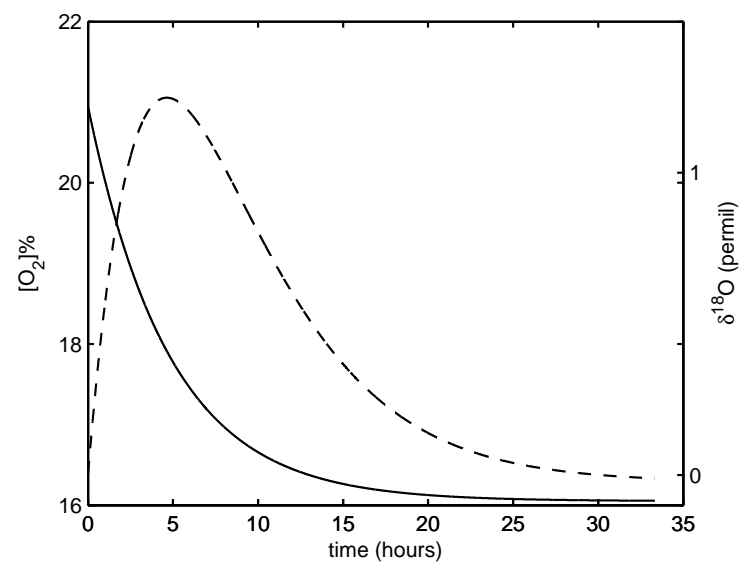

Fig. 1. Modelled $\mathrm{O}_{2}$ concentrations (solid line) and $\delta^{18} \mathrm{O}$ values (dashed line, versus atmospheric air) in the stem chamber, for a model run with $D_{\text {stem }}=14 \%$.

\section{Results}

In the air from the blank experiment, the $\delta^{18} \mathrm{O}$ and $\delta \mathrm{O}_{2} / \mathrm{Ar}$ were $-0.07 \%$ and $-6 \%$, respectively. The results of all the stem chambers experiments are summarized in Table 1 . The discrimination values $(D)$ ranged from $12.0 \%$ to $21.5 \%$ o. Discrimination in the range of 14-16\%o was the most common and was found in 9 out of the 21 experiments. Discrimination below 16.5 was found in almost all the Apple tree experiments, excluding the one conducted shortly after bud burst in April 2010, in which the discrimination was $21.5 \%$. The Mari-Mari trees' discrimination was $15.2-15.3 \%$, while the Tanagrana trees' range was $16.6-18.1 \%$, and the range for the Marupa trees was the widest: $15.2-19.8 \%$.

\section{Discussion}

The estimate of the discrimination by Eq. (3) is based on the assumption that the gas transport to the chamber is dominated by gas-phase diffusion. In other words, we assume that $\mathrm{O}_{2}$ did not enter the chambers by mass flow. Entrance of $\mathrm{O}_{2}$ by mass flow is with no isotopic discrimination, and hence using the parameter of $14.1 \%$ in Eq. (3) will bias $D_{\text {stem }}$ toward higher values, if the assumption of dominating diffusion gas exchange is not valid. However, this assumption is supported by two tests we have made. First, we have successfully tested the chambers for leaks (see Sect. 2). Second, we have conducted an experiment on the Apple tree especially to test the assumption of dominating gas-phase diffusion. In this test, we have flushed the chamber at the beginning of the experiment with $\mathrm{N}_{2}$ gas. In this condition, the initial gas exchange between the chamber and the atmosphere brings in $\mathrm{O}_{2}$ to the chamber. Oxygen entering by mass flow will enter with the same isotopic value of the atmosphere oxygen $\left(\delta^{18} \mathrm{O}=0 \%\right)$, while oxygen entering by diffusion will 
Table 1. Summary of the stem chamber experiments. The $D_{\text {stem }}$ error is calculated from the analytical uncertainty.

\begin{tabular}{llllrrrrr}
\hline Tree & Site & $\begin{array}{l}\text { Experiment } \\
\text { month and } \\
\text { year }\end{array}$ & Comments & $\begin{array}{r}\text { Experiment } \\
\text { duration } \\
\text { (hours) }\end{array}$ & $\begin{array}{r}{\left[\mathrm{O}_{2}\right]} \\
\%\end{array}$ & $\delta^{18} \mathrm{O}$ & $\begin{array}{r}D_{\text {stem }} \\
\text { (n) }\end{array}$ & $\begin{array}{r}D_{\text {stem }} \\
\text { error }\end{array}$ \\
\hline Aleppo Pine & HUJI & July 2010 & & 141 & 19.67 & 0.06 & 15.2 & 0.5 \\
Aleppo Pine & HUJI & December 2011 & & 117 & 18.85 & 0.24 & 16.5 & 0.3 \\
Aleppo Pine & HUJI & January 2011 & & 48 & 19.30 & -0.12 & 12.6 & 0.4 \\
Aleppo Pine & HUJI & January 2011 & & 48 & 19.30 & -0.02 & 13.8 & 0.4 \\
Stone Pine & HUJI & July 2010 & & 141 & 18.56 & 0.21 & 16.0 & 0.3 \\
Apple & HUJI & April 2010 & after bud burst & 51 & 17.89 & 1.06 & 21.4 & 0.3 \\
Apple & HUJI & April 2010 & after bud burst & 51 & 17.80 & 1.11 & 21.5 & 0.3 \\
Apple & HUJI & December 2010 & green leaves & 96 & 19.68 & 0.11 & 15.9 & 0.5 \\
Apple & HUJI & December 2010 & green leaves & 117 & 19.68 & 0.09 & 15.5 & 0.5 \\
Apple & HUJI & January 2011 & green leaves & 48 & 19.78 & -0.06 & 13.0 & 0.5 \\
Apple & HUJI & January 2011 & green leaves & 48 & 19.77 & -0.12 & 12.0 & 0.5 \\
Apple & HUJI & March 2011 & no leaves & 120 & 19.57 & 0.08 & 15.4 & 0.5 \\
Apple & HUJI & March 2011 & no leaves & 144 & 19.44 & 0.03 & 14.5 & 0.4 \\
Mari Mari 1 & UNAP & April 2011 & wet season & 240 & 19.55 & 0.08 & 15.3 & 0.5 \\
Mari Mari 3 & UNAP & April 2011 & wet season & 240 & 18.83 & 0.11 & 15.2 & 0.3 \\
Marupa 1 & UNAP & April 2011 & wet season & 240 & 17.37 & 0.19 & 15.2 & 0.2 \\
Marupa 2 & UNAP & April 2011 & wet season & 240 & 16.76 & 1.08 & 19.5 & 0.2 \\
Marupa 3 & UNAP & April 2011 & wet season & 240 & 18.36 & 0.70 & 19.8 & 0.3 \\
Tangarana 1 & UNAP & April 2011 & wet season & 240 & 19.48 & 0.28 & 18.1 & 0.5 \\
Tangarana 2 & UNAP & April 2011 & wet season & 240 & 16.15 & 0.57 & 16.6 & 0.1 \\
Tangarana 3 & UNAP & April 2011 & wet season & 240 & 17.70 & 0.40 & 16.6 & 0.2 \\
\hline & & & & & & & \\
\hline
\end{tabular}

have negative $\delta^{18} \mathrm{O}$ values (versus the atmosphere), due to fractionation by diffusion. Thus, if diffusion transport dominates, the oxygen in the chambers is expected to have negative $\delta^{18} \mathrm{O}$ values that will increase with time as a result of back-diffusion (also with a discrimination of $14.1 \%$ ) and as a result of uptake by the stem. The results of this experiment, already published (Angert and Sherer, 2011), showed negative $\delta^{18} \mathrm{O}$ values of $-3.15 \%$ and $-2.58 \%$, 2 and $4 \mathrm{~h}$ after the beginning of the experiment, respectively. The results of that experiment, as well as a fit of the model to it (achieved while assuming that the flushing with $\mathrm{N}_{2}$ removed $90 \%$ of the air in the chamber and stem pores next to it, and $D=25 \%$ which might be the result of the low $\mathrm{O}_{2}$ stress) are shown in Fig. 2. Based on these two lines of evidence, and based on the absence of strong winds or strong diurnal temperature changes (especially in the tropical forest), we conclude that mass flow to the chambers was negligible. Another process that might introduce mass flow is changes in atmospheric pressures. However, we sampled during fair weather in which the atmospheric pressure changes (as recorded by nearby meteorological stations) were $<6 \mathrm{hPa}$. Our model shows that such pressure change will have an effect on estimate $D$ in the order of $0.1 \%$. However, care should be taken to avoid setting such experiments during periods of sharp changes in pressure. The results of the blank experiment aimed to test the effect of water vapor diffusion (Severinghaus et al., 1996), are as predicted from theory - small and with negligible effect on our discrimination estimations.
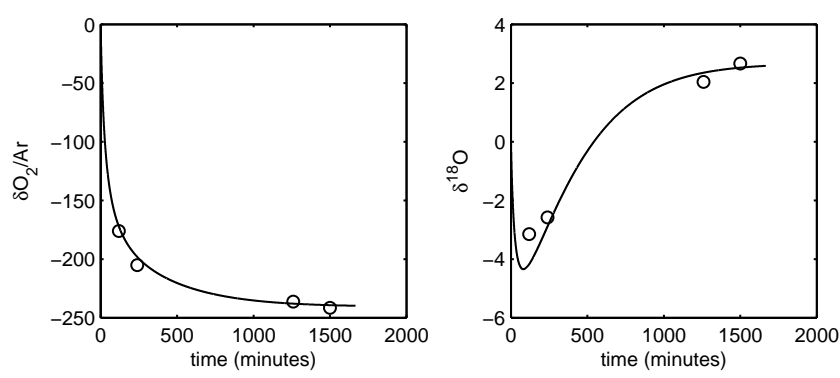

Fig. 2. Measured (open circles) and modelled (solid line) $\delta \mathrm{O}_{2} / \mathrm{Ar}$ values and $\delta^{18} \mathrm{O}$ values (both in permil versus atmospheric air) during the experiment which started with flushing the chamber on the Apple tree with $\mathrm{N}_{2}$. The model assumes constant respiration rate and discrimination. The results of this experiment are consistent with diffusion being the main driver of gas exchange in the chamber.

We found frequent occurrence of low discrimination values, in the range of 12-16\% which are well below the known values for COX respiration in isolated plant mitochondria, which is $\sim 20 \%$, (Ribas-Carbo et al., 1995). The low values are most probably not related to variation in the COX in different plant species, since discrimination of $\sim 20 \%$ o was also reported for the much more genetically remote marine eukaryotes and marine bacteria (Kiddon et al., 1993). Hence, the low value we measured can be explained only by the effect of diffusion limiting the internal $\mathrm{O}_{2}$ concentration. As was found for soils, limiting diffusion of $\mathrm{O}_{2}$ to the 
consumption site makes the effective discrimination lower than the one involved in the enzymatic respiration process by itself with no limit to the supply of $\mathrm{O}_{2}$. Again as in soils, we can suggest a conceptual model of "a box within box", in which oxygen first diffuses in gas phase through the stem ("outer box"), and then diffuses in liquid phase to the consumption site within living cells ("inner box"). The discrimination by the combined effects of diffusion into the inner box and enzymatic $\mathrm{O}_{2}$ consumption within it, is given by the following equation (after Farquhar et al., 1982):

$D^{\prime}=D_{\text {diff }^{\prime}}+\left(D_{\text {con }}-D_{\text {diff' }}\right) C_{\mathrm{i}} / C_{\mathrm{a}}$,

where $D^{\prime}$ is the overall discrimination of the inner box, $D_{\text {con }}$ is the discrimination in consumption, $D_{\mathrm{diff}^{\prime}}$ is the discrimination in diffusion to the inner box, and $C_{\mathrm{a}}$ and $C_{\mathrm{i}}$ are the $\mathrm{O}_{2}$ concentrations outside and inside the inner box, respectively. The discrimination of the entire stem $\left(D_{\text {stem }}\right)$ will relate to the discrimination of the inner box $\left(D^{\prime}\right)$ by a similar equation:

$D_{\text {stem }}=D_{\text {diff }}+\left(D^{\prime}-D_{\text {diff }}\right) C_{\mathrm{i}} / C_{\mathrm{a}}$,

where $D_{\text {diff }}$ is the discrimination in diffusion through the stem, which is $14.1 \%$ assuming that this diffusion is in gas phase. According to Equations 4 and 5, the $D_{\text {stem }}$ values below $14 \%$ can only be explained if the diffusion to the inner box is by liquid phase diffusion, in which the discrimination is small (2.7\%o discrimination was found for $\mathrm{O}_{2}$ air-water gas transfer; Knox et al., 1992).

The differences observed between tree species could reflect variations in structural barriers to diffusion. Indeed, Marupa, the tropical tree in which the highest discrimination was measured, has a reported wood density of only $0.35 \mathrm{~g} \mathrm{ml}^{-1}$ versus 0.53 and $0.65 \mathrm{~g} \mathrm{ml}^{-1}$ for Mari-Mari and Tangarana (Chambers et al., 2004). However, the diffusivity depends not only on the density (and hence porosity) of the stem, but also on the water content which may vary, and on the structure of the air-filled pore spaces (Sorz and Hietz, 2006). We currently do not have data on diffusivity values of the live tissue.

Variations in diffusivity (resulting in lower discrimination values) cannot explain the discrimination measurements that are greater than those expected for the cytochrome (COX) pathway respiration (20\%). The only known process that can result in higher discrimination values is the engagement of the AOX respiration pathway. Moreover, since it is reasonable to assume that the diffusion limitation always exists, the discrimination values above $19.5 \%$ as those in some of the Marupa trees, also indicate large contributions of the AOX pathway (relative to the COX), which shift the overall discrimination to higher values, and compensate for the effects of diffusion. With time, the changes in discrimination in the Apple tree resemble variation in the range of 12.3 to $19.9 \%$, observed for the same root system in the course of a few weeks (Angert and Luz, 2001), and are probably also related to changes in the relative contribution of AOX to total respiration $\mathrm{O}_{2}$ consumption.

Our findings have implications for estimating the average land contribution to the Dole Effect, as well as for estimating the variability and uncertainty of this value. The average of the stem experiments in the current study is $16 \%$. However, we observed large variability in discrimination values with season, between species, and within species, so this value cannot be assumed to be globally representative. If the value of globally averaged discrimination in stem uptake happens to be $16 \%$, then assuming that stem's respiration consists of $16 \%$ (Litton et al., 2007) of the land respiration, the estimation of the land contribution to the Dole Effect will be lower than $0.3 \%$ orelative to an estimate that uses a discrimination value of $18 \%$ for all land dark respiration (Blunier et al., 2002). This $0.3 \%$ value is small in comparison to other uncertainties in estimating the land Dole Effect (Luz and Barkan, 2011). However, the paleo data point to variability in the land Dole Effect in the order of only $0.5 \%$ (Severinghaus et al., 2009). If we assume a shift from an average stem discrimination of $15 \%$ o to $19 \%$ (well within our measured range of $12.0-21.5 \%$ ), it will induce a shift of $\sim 0.6 \%$ in the land Dole Effect. This effect is in similar magnitude to that resulting from possible changes in the discrimination by soils, which were suggested (Severinghaus et al., 2009) to partly explain past changes in the Dole Effect. This soils effect was suggested to result from variations in the activity of tropical soil respiration, shown to be diffusion-limited and have low discrimination, relative to the activity of boreal forest, where engagement of AOX resulted in high discrimination. However, given that to date there are only two surveys of the discrimination in various soil sites (Angert et al., 2003, 2012), and considering the variability reported here for stem discrimination, many more studies must be conducted before the variability in the Dole Effect can be reliably interpreted.

Another important implication of our findings is for estimating the contribution of the AOX to respiration and the carbon cycle. To the best of our knowledge, this study is the only one to date that has estimated AOX activity in intact plants in the field. Given the known relation between AOX and various types of stress (Vanlerberghe and McIntosh, 1997; Moore et al., 2002; Rachmilevitch et al., 2007), working with intact plants has a clear advantage over incubating desiccated plant tissue (Ow et al., 2008; Searle and Turnbull, 2011) that might exhibit a wound response. Using the approach demonstrated here, it is possible to trace how the AOX contribution in woody tissue of a single plant changes seasonally, and due to environmental conditions such as temperature and soil moisture. For example, we found the highest discrimination in the Apple tree shortly after bud burst, which somewhat resembles the high discrimination reported for aquatic systems shortly after spring bloom (Luz and Barkan, 2011). These findings are in agreement with findings of increased AOX activity shortly after changes in environmental conditions, or before an increase in the rates of respiration through 
the COX (Moore et al., 2002; Rachmilevitch et al., 2007). As noted above, the AOX is also reported to be activated as a response to stress. We thus believe that more field studies of the AOX will improve the understanding of the carbon cycle and its sensitivity to climate induced changes in respiration.

\section{Conclusions}

We have measured, for the first time, the $\mathrm{O}_{2}$ discrimination associated with respiration of intact tree stems. We have found, as predicted from theory, evidence for both the effect of slow diffusion that limits the internal $\mathrm{O}_{2}$ concentrations and lowers the discrimination, and the effect of the AOX that increases it. As a result of these two contrasting processes, the discrimination in stem uptake is highly variable and covers the range of 12.6-21.5\% . Our findings have implications for understanding past variations in the Dole Effect, and for tracing the AOX activity in intact plants at the field.

Acknowledgements. We thank Eugeni Barkan and Eyal Wurgaft for help with the $\mathrm{O}_{2}$ analysis. A. A. was partly supported by ISF grant \#870/08.

Edited by: A. Shemesh

\section{References}

Angert, A. and Luz, B.: Fractionation of oxygen isotopes by root respiration: Implications for the isotopic composition of atmospheric $\mathrm{O}_{2}$, Geochim. Cosmochim. Ac., 65, 1697-1703, 2001.

Angert, A. and Sherer, Y.: Determining the relationship between tree-stem respiration and $\mathrm{CO}_{2}$ efflux by $d \mathrm{O}_{2} / \mathrm{Ar}$ measurements, Rapid Commun. Mass Spectrom., 25, 1752-1756, 2011.

Angert, A., Luz, B., and Yakir, D.: Fractionation of oxygen isotopes by respiration and diffusion in soils and its implications for the isotopic composition of atmospheric $\mathrm{O}_{2}$, Global Biogeochem. Cy., 15, 871-881, 2001.

Angert, A., Barkan, E., Barnett, B., Brugnoli, E., Davidson, E. A., Fessenden, J., Maneepong, S., Panapitukkul, N., Randerson, J. T., Savage, K., Yakir, D., and Luz, B.: The contribution of soil respiration in tropical, temperate, and boreal forests to the ${ }^{18} \mathrm{O}$ enrichment of atmospheric $\mathrm{O}_{2}$, Global Biogeochem. Cy., 17, 1089, doi:10.1029/2003GB002056, 2003.

Angert, A., Rodeghiero, M., and Griffin, K.: High alternative oxidase activity in cold soils and its implication to the Dole Effect, Geophys. Res. Lett., 39, L16710, doi:10.1029/2012GL052719, 2012.

Barkan, E. and Luz, B.: High-precision measurements of ${ }^{17} \mathrm{O} /{ }^{16} \mathrm{O}$ and ${ }^{18} \mathrm{O} /{ }^{16} \mathrm{O}$ of $\mathrm{O}_{2}$ and $\mathrm{O}_{2} / \mathrm{Ar}$ ratio in air, Rapid Commun. Mass Spectrom., 17, 2809-2814, doi:10.1002/rcm.1267, 2003.

Beer, C., Reichstein, M., Tomelleri, E., Ciais, P., Jung, M., Carvalhais, N., Rodenbeck, C., Arain, M. A., Baldocchi, D., Bonan, G. B., Bondeau, A., Cescatti, A., Lasslop, G., Lindroth, A., Lomas, M., Luyssaert, S., Margolis, H., Oleson, K. W., Roupsard, O., Veenendaal, E., Viovy, N., Williams, C., Woodward, F. I., and Papale, D.: Terrestrial Gross Carbon Dioxide Uptake: Global Dis- tribution and Covariation with Climate, Science, 329, 834-838, doi:10.1126/science.1184984, 2010.

Bender, M., Sowers, T., and Labeyrie, L.: The Dole effect and its variations during the last 130,000 years as measured in the Vostok ice core, Global Biogeochem. Cy., 8, 363-376, 1994.

Blunier, T., Barnett, B., Bender, M. L., and Hendricks, M. B.: Biological oxygen productivity during the last 60,000 years from triple oxygen isotope measurements, Global Biogeochem. Cy., 16, 1029, doi:10.1029/2001GB001460, 2002.

Brohan, P., Kennedy, J. J., Harris, I., Tett, S. F. B., and Jones, P. D.: Uncertainty estimates in regional and global observed temperature changes: A new data set from 1850, J. Geophys. Res., 111, D12106, doi:10.1029/2005jd006548, 2006.

Chambers, J. Q., Higuchi, N., Teixeira, L. M., dos Santos, J., Laurance, S. G., and Trumbore, S. E.: Response of tree biomass and wood litter to disturbance in a Central Amazon forest, Oecologia, 141, 596-611, doi:10.1007/s00442-004-1676-2, 2004.

Eisenstadt, D., Barkan, E., Luz, B., and Kaplan, A.: Enrichment of oxygen heavy isotopes during photosynthesis in phytoplankton, Photosynth. Res., 103, 97-103, doi:10.1007/s11120-009-9518-z, 2010.

Farquhar, G. D., O'Leary, M. H., and Berry, J. A.: On the relationship between carbon isotope discrimination and the intercellular carbon dioxide concentration in leaves, Aust. J. Plant Physiol., 9, 121-137, 1982.

Farquhar, G. D., Lloyd, J., Taylor, J. A., Flanagan, L. B., Syvertsen, J. P., Hubick, K. T., Wong, S. C., and Ehleringer, J. R.: Vegetation effects on the isotope composition of oxygen in atmospheric $\mathrm{CO}_{2}$, Nature, 363, 439-443, 1993.

Gillon, J. and Yakir, D.: Infulence of carbonic anhydrase activity in terrestrial vegetation on the ${ }^{18} \mathrm{O}$ content of atmospheric $\mathrm{CO}_{2}$, Science, 291, 2584-2587, 2001.

Guy, R. D., Berry, J. A., Fogel, M. L., and Hoering, T. C.: Differential fractionation of oxygen isotopes by cyanide-resistant and cyanide-sensitive respiration in plants, Planta, 177, 483-491, 1989.

Guy, R. D., Fogel, M. L., and Berry, J. A.: Photosynthetic fractionation of the stable isotopes of oxygen and carbon, Plant Physiology Rockville, 101, 37-47, 1993.

Kiddon, J., M. L. Bender, Orchardo, J., Caron, D. A., Goldman, J. C., and Dennett, M.: Isotopic fractionation of oxygen by respiring marine organisms, Global Biogeochem. Cy., 7, 679-694, 1993.

Knox, M., Quay, P. D., and Wilbur, D.: Kinetic Isotopic Fractionation During Air-Water Gas Transfer of $\mathrm{O}_{2}, \mathrm{~N}_{2}, \mathrm{CH}_{4}$, and $\mathrm{H}_{2}$, J. Geophys. Res., 97, 20335-20343, doi:10.1029/92jc00949, 1992.

Lane, G. A. and Dole, M.: Fractionation of oxygen isotopes during respiration, Science, 123, 574-576, 1956.

Litton, C. M., Raich, J. W., and Ryan, M. G.: Carbon allocation in forest ecosystems, Glob. Change Biol., 13, 2089-2109, doi:10.1111/j.1365-2486.2007.01420.x, 2007.

Luz, B. and Barkan, E.: The isotopic composition of atmospheric oxygen, Global Biogeochem. Cy., 25, GB3001, doi:10.1029/2010gb003883, 2011.

Moore, A. L., Albury, M. S., Crichton, P. G., and Affourtit, C.: Function of the alternative oxidase: is it still a scavenger?, Trends Plant Sci., 7, 478-481, 2002.

Ow, L. F., Whitehead, D., Walcroft, A. S., and Turnbull, M. H.: Thermal acclimation of respiration but not 
photosynthesis in Pinus radiata, Funct. Plant Biol., 35, 448-461, doi:10.1071/fp08104, 2008.

Rachmilevitch, S., Xu, Y., Gonzalez-Meler, M. A., Huang, B., and Lambers, H.: Cytochrome and alternative pathway activity in roots of thermal and non-thermal Agrostis species in response to high soil temperature, Physiol. Plantarum, 129, 163 174, doi:10.1111/j.1399-3054.2006.00784.x, 2007.

Ribas-Carbo, M., Berry, J. A., Yakir, D., Giles, L., Robinson, S. A., Lennon, A. M., and Siedow, J. N.: Electron Partitioning between the Cytochrome and Alternative Pathways in Plant Mitochondria, Plant Physiol., 109, 829-837, 1995.

Ryan, M. G., Lavigne, M. B., and Gower, S. T.: Annual carbon cost of autotrophic respiration in boreal forest ecosystems in relation to species and climate, J. Geophys. Res., 102, 28871-28883, doi:10.1029/97jd01236, 1997.

Searle, S. Y. and Turnbull, M. H.: Seasonal variation of leaf respiration and the alternative pathway in field-grown Populus x canadensis, Physiol. Plantarum, 141, 332-342, doi:10.1111/j.1399-3054.2010.01442.x, 2011.

Severinghaus, J. P., Bender, M. L., Keeling, R. F., and Broecker, W. S.: Fractionation of soil gases by diffusion of water vapor, gravitational settling, and thermal diffusion, Geochim. Cosmochim. Ac., 60, 1005-1018, 1996.
Severinghaus, J. P., Beaudette, R., Headly, M. A., Taylor, K., and Brook, E. J.: Oxygen- 18 of $\mathrm{O}_{2}$ Records the Impact of Abrupt Climate Change on the Terrestrial Biosphere, Science, 324, 14311434, doi:10.1126/science.1169473, 2009.

Sorz, J. and Hietz, P.: Gas diffusion through wood: implications for oxygen supply, Trees - Struct. Funct., 20, 34-41, doi:10.1007/s00468-005-0010-x, 2006.

Ubierna, N., Marshall, J. D., and Cernusak, L. A.: A new method to measure carbon isotope composition of $\mathrm{CO}_{2}$ respired by trees: stem $\mathrm{CO}_{2}$ equilibration, Funct. Ecol., 23, 1050-1058, doi:10.1111/j.1365-2435.2009.01593.x, 2009.

Vanlerberghe, G. C. and McIntosh, L.: Alternative oxidase: From gene to function, Annu. Rev. Plant Phys., 48, 703-734, doi:10.1146/annurev.arplant.48.1.703, 1997.

Waring, R. H., Landsberg, J. J., and Williams, M.: Net primary production of forests: a constant fraction of gross primary production?, Tree Physiol., 18, 129-134, doi:10.1093/treephys/18.2.129, 1998. 